\title{
18. PETROGRAPHY OF DEGRADED PLANT FRAGMENTS FROM PALEOCENE-EOCENE SEDIMENTS OF DEEP SEA DRILLING PROJECT LEG 81, SITE 555, ROCKALL PLATEAU ${ }^{1}$
}

\author{
Jane Lund and Walter Riegel, Geologisch-Paläontologisches Institut und Museum der Universitat, Göttingen ${ }^{2}$
}

\begin{abstract}
Twenty-four sediment samples from late Paleocene to early Eocene were studied for maceral content, vitrinite reflectance, and spectral fluorescence in order to determine some parameters of the origin and diagenetic history of their organic fraction. The sediments had been obtained at Site 555 of DSDP Leg 81 in the northeastern North Atlantic. The bulk of the microscopically visible fraction is made up of humic materials; inertinites follow as a distant second; and liptinites are exceedingly rare. No unequivocal evidence of marine organic matter was found. Humic materials are highly decomposed, showing signs of aerobic (frequency of sclerotinites) as well as anaerobic (abundance of and intimate association with framboidal pyrite) microbial degradation. Vitrinite reflectance values vary between 0.26 and $0.35 R_{o}$ and show a slight increase with depth. These values, indicative of a low-rank lignite stage of coalification, contrast somewhat with the sporinite fluorescence spectra, which show the configuration typical for the peat stage. In either case, the evidence for such a low stage of coalification is surprising in view of the depth and age of the sediments.
\end{abstract}

\section{INTRODUCTION}

A considerable abundance of plant debris has been reported from several levels of Deep Sea Drilling Project (DSDP) Site 555 in carbonaceous sandstones, siltstones, and mudstones dated as late Paleocene and early Eocene and forming a more than 500-m-thick sequence with interbedded volcanic tuffs and basaltic lava flows. Inspection of core material from these levels at low to intermediate magnification failed to reveal any tissue structures by which the nature and origin of the carbonaceous material could be identified. In order to obtain some information on the type of particulate organic matter present and its mode of preservation, 24 samples were selected for microscopic investigation by coal petrographic methods under reflected light and blue-light irradiation. To assess the state of maceral formation with respect to coalification some parameters of rank such as vitrinite reflectance and sporinite fluorescence spectra were needed.

For this purpose small blocks of core material, about $1 \mathrm{~cm}$ in length, were impregnated and embedded in synthetic resin, then ground and polished in several stages up to aluminum oxide. Repeated reimpregnation between polishing stages proved necessary in order to reduce the formation of relief and scratches as well as the breaking away of particles in a rather porous rock consisting of components with greatly differing polishing behavior. Organic particles usually form a strong positive relief within a predominantly soft clayey rock matrix, but they more often form a distinct negative relief when closely associated with pyrite.

Sixteen samples proved to contain at least small amounts of macerals, but only eight produced the particle size or

\footnotetext{
${ }^{1}$ Roberts, D. G., Schnitker, D., et al., Init. Repts. DSDP, 81: Washington (U.S. Govt. Printing Office).

2 Addresses: (Lund) Friedrich-Hoffmann-Strasse 8, 3109 Wietze, Federal Republic of Germany; (Riegel) Geologisch-Paläontologisches Institut und Museum der Universităt, D3400 Göttingen, Goldschmidt Strasse 3, Federal Republic of Germany.
}

quantity of humic macerals necessary for vitrinite reflectance measurements and only two contained the sporinite material suitable for spectral fluorimetry. Two core sections (Sections 555-38-2 and 46-6) provided a spectrum of macerals broad enough to form the basis of the following descriptions.

The geographic position of Site $555\left(56^{\circ} 33.70^{\prime} \mathrm{N}\right.$, $20^{\circ} 46.93^{\prime} \mathrm{W}$ ) is shown with respect to major topographic features in Figure 1. Water depth at the drilling site is given as $1659 \mathrm{~m}$. The sampled interval for this study ranges from 355 to $900 \mathrm{~m}$ sub-bottom depth.

\section{MACERALS-TYPOLOGY, DISTRIBUTION, AND ASSOCIATION}

In this chapter, solid organic components are referred to as macerals rather than kerogen, since maceral terminology and classification provide more detail and precise definition, particularly with regard to the terrestrial organic matter making up the bulk of the organic fraction. Table 1 presents estimates of the relative frequency of maceral groups from two organic-rich samples; it shows the great predominance of the huminite group (vitrinite precursors), with inertinites following as a distant second and liptinites being exceedingly rare. An apparent feature of all macerals is their intimate association with framboidal and microcrystalline pyrite.

\section{Huminite Group}

Based on microscopic appearance and coalification parameters, all lignin and cellulose-derived material is obviously preserved in the huminite stage of coalification except for fusinite, semifusinite, and some inertodetrinite. Most huminite macerals appear to be highly degraded. Exceptional examples show intact tissue structure and ungelified but not fluorescing cell walls, thus representing the textinite B maceral type (Plate 1, Figs. 5, 6). Even in these cases cell lumina are frequently filled with corpohuminites, mainly porigelinites and some phlobaphi- 


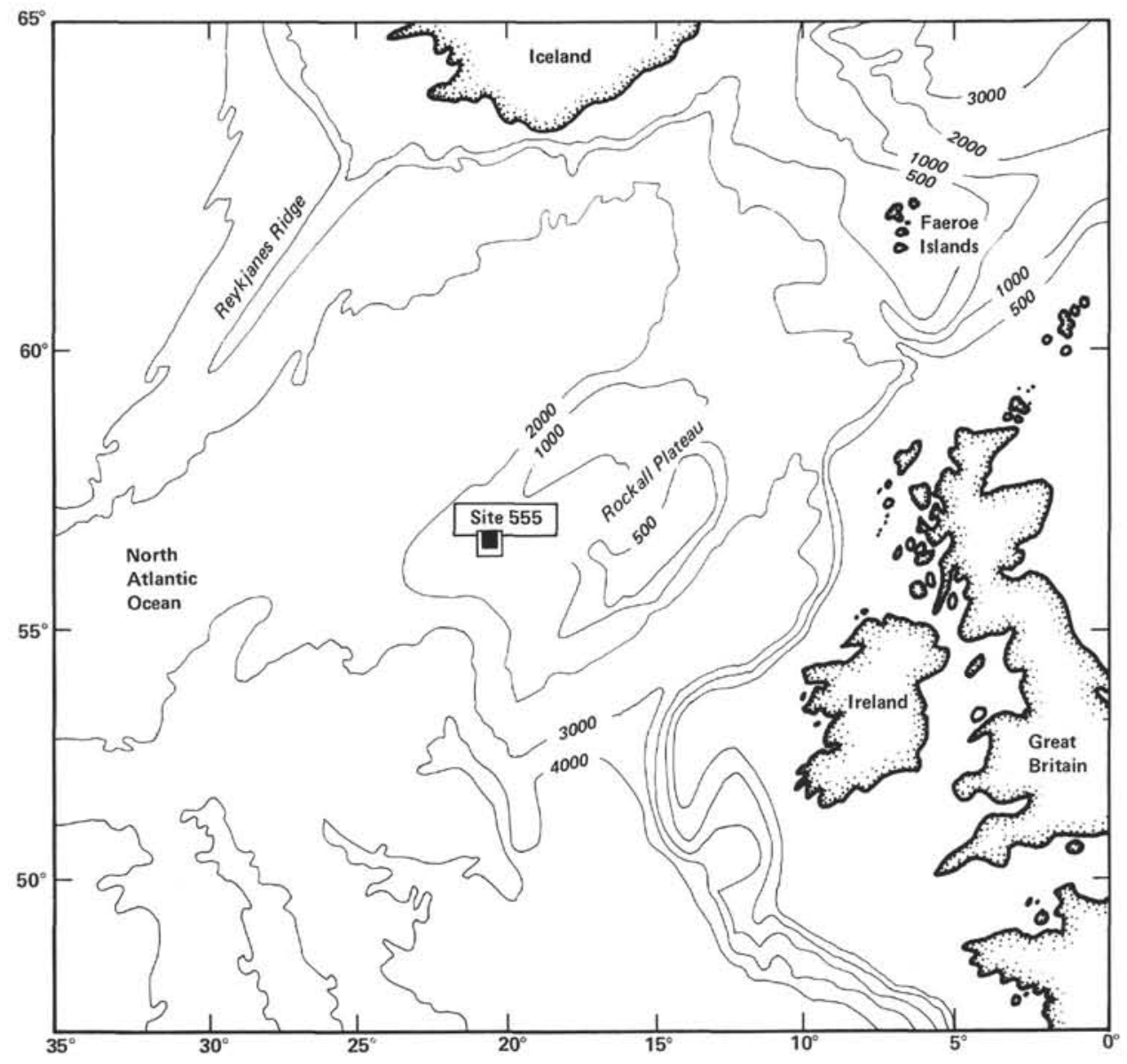

Figure 1. Location of Site 555.

Table 1. Maceral distribution of two organic-rich sections, based on point counts in percent, Hole 555.

\begin{tabular}{|c|c|c|c|c|c|c|c|}
\hline \multirow[b]{2}{*}{ Core-Section } & \multicolumn{3}{|c|}{ Huminites } & \multirow[b]{2}{*}{ Liptinite } & \multicolumn{2}{|c|}{ Inertinite } & \multirow{2}{*}{$\begin{array}{l}\text { Frequency } \\
\text { ratio of } \\
\text { maceral:pyrite: } \\
\text { mineral matrix }\end{array}$} \\
\hline & $\begin{array}{c}\text { Humo- } \\
\text { detrinite }\end{array}$ & $\begin{array}{l}\text { Corpo- } \\
\text { huminite }\end{array}$ & $\begin{array}{c}\text { Other } \\
\text { huminites }\end{array}$ & & $\begin{array}{l}\text { Fusinite } \\
\text { Semifusinite }\end{array}$ & $\begin{array}{l}\text { Sklero- } \\
\text { tinite }\end{array}$ & \\
\hline $38-2$ & 67.6 & 4.4 & 16.2 & 7.4 & 1.5 & 2.9 & $1: 1.6: 10.4$ \\
\hline $46 \cdot 6$ & 62.2 & 11.3 & 13.2 & 3.8 & 1.9 & 7.6 & $1: 0.8: 8.2$ \\
\hline
\end{tabular}

nites. More often these corpohuminites occur as dense and more-or-less regular clusters (Plate 1, Figs. 4, 7), indicating their previous position within the original host tissue, but with little or no cell wall material preserved. This strongly implies that decomposition of cell wall material took place to a considerable degree subsequent to the incorporation of plant fragments in the sediment. It is interesting to note that normal porigelinites occur in close association with corpohuminites containing moreor-less dense clusters of microcrystalline pyrite (Plate 1, Figs. 5,7 ). Since these pyrite crystals are completely enclosed within the corpohuminite matrix, corpohuminite formation seems to have progressed subsequent to pyrite invasion, though evidence of gelification and postdepositional alteration of macerals is otherwise rare. Levigelinite fragments showing desiccation cracks have occasionally been recorded (Plate 1, Fig. 3). Presumably they formed prior to incorporation into the sediment and were brought in as part of the sedimentary detritus, though the desiccation cracks must have developed later.

Highly degraded humic material occurs in three ways:

1. If it is concentrated in thin bands indicating the bedding plane, it is usually intimately associated with framboidal pyrite. Remnants of textinite appear to surround or fill the voids between the pyritic framboids. They are somewhat obscured as a result of the high relief and high reflectivity of the pyritic framboids.

2 . If highly degraded humic material occurs more massively, it may resemble or even assume the texture of attrinite. Figure 1 of Plate 1 shows the transition from a mass of corpohuminites, apparently still occurring in their original tissue connection, through a band of attrinite, to an almost totally pyritized zone. The section in this case is cut perpendicular to the bedding plane and may suggest the normal succession of stages of degradation along a redox gradient forming within a plant fragment 
at or near the surface of the sediment in an oxygen-deficient environment. Figure 8 of Plate 1 may serve as an illustration of a degradational stage intermediate between textinite and attrinite.

3. The material may occur rather diffuse and slightly concentrated in small pockets of fine-grained mineral matrix (Plate 1, Fig. 9) that contrast sharply with the coarsegrained immature sediment. The organic matter is here distinguished from amorphous kerogen by the total lack of fluorescence. Pyritic framboids are more evenly distributed in these pockets, showing no particular preference to the humic detritus. These pockets may variously be interpreted as fecal pellets, cross sections of tiny animal burrows, or, most likely, rock fragments.

\section{Liptinite Group}

Macerals of the liptinite group are exceedingly rare in Paleocene-Eocene sediments at DSDP Site 555. Sporinite has been found rather regularly only in Section 555$46-6$, where it is represented mainly by uncompressed tricolpate or bisaccate pollen grains totally or partially filled with pyrite of the framboidal type (Plate 2, Fig. 6). Cutinite (present only in Section 46-6) occurs either as (1) very thin cuticles covering bands of corpohuminites mixed with abundant pyritic framboids, which lack, however, cell wall material (textinite, Plate 2, Fig. 1, 2) or as (2) relatively thick-walled cuticular fragments (Plate 2, Fig. 5). Apparently only the thick-walled cuticles survived detachment and some degree of transport, while thin cuticles are preserved only in situ or partially detached around remnants of leaf mesophyll. Resinite bodies very rarely occur as cell fillings (Plate 1, Fig. 2) or isolated. Even liptodetrinite is exceptionally rare, being effectively restricted to the pockets of fine-grained mineral matrix interpreted above as possible fecal pellets or grains of reworked clay. The only possible evidence of aquatic algal material is very sporadic occurrences of thin structureless folded membranes resembling alginite B (Plate 2, Fig. 4).

\section{Inertinite Group}

Inertinite macerals are also infrequent but clearly more common than those of the liptinite group. Two types occur: fusinite and sclerotinite. Fusinite is normally represented by fragments showing sieve structure in which the cavities are frequently filled with framboidal pyrite (Plate 2, Fig. 7). But fragments of the degradofusinite type also occur along with some semifusinite.

Sclerotinites are represented by several varieties. Most common are various forms and sizes of the sclerotitestype fungal sclerotia (Plate 2, Figs. 10, 11), but spherical thick-walled fungal spores about $40 \mu \mathrm{m}$ in diameter commonly appear in some samples. Less frequent are several-celled teleutospores (Plate 2, Fig. 12). Occasionally, fragments or small bodies of fungal plectenchyma (Plate 2, Figs. 8, 9) or cross sections of individual hyphae are encountered. Framboidal pyrite fillings in sclerotinite cavities are common, but apparently less frequent than in fusinite. The reflectance of some of the sclerotinites is surprisingly low.

\section{REFLECTANCE MEASUREMENTS}

Vitrinite reflectance measurements have been carried out with the aim of obtaining coalification parameters for the assessment of maceral development, especially in the huminite group. The values demonstrate that in this cycle of sedimentation, organic particles have only gone through the biological stage of coalification, and all lignin- and cellulose-derived materials are preserved in the stage of vitrinite precursors, i.e., huminites.

Of the 24 samples prepared, only 6 provided the size and quantity of huminites suitable for significant reflectance measurements. Individual measurements were obtained from two additional samples. Several other samples contained abundant humodetrinite particles too small for measurement; the remainder were effectively barren.

The vitrinite reflectance values represented in Tables 2 and 3 vary between 0.26 and $0.35 \% R_{o}$. They include only those values considered to be primary vitrinites. The considerable number of vitrinites with distinctly higher values in most samples suggests resedimentation of organic particles from previous sedimentary cycles. From Table 2 it becomes evident that the values can be grouped into two classes, reflecting a general trend towards increasing coalification with depth: The three values obtained from above the $400-\mathrm{m}$ sub-bottom level are less than $0.30 \% R_{o}$, those from below this level are greater than $0.30 \% R_{o}$. The values of the latter group are equivalent to values obtained by Kendrick, Hood, and Castaño (1979) from somewhat shallower depth at DSDP Sites 403 and 404 about $250 \mathrm{~km}$ to the west of Site 555 and from similar depths at Hole $402 \mathrm{~A}$ at the Bay of Biscay continental margin. The low level of these vitrinite reflectance values requires at least that no vitrinite reflectance values requires at least that no incurred at any time since the late Paleocene, despite the volcanic activity taking place prior to and during early Tertiary sedimentation.

\section{FLUORESCENCE SPECTRA}

Since vitrinite reflectance measurements are considered less reliable at very low ranks of coalification, sporinite fluorescence was applied to corroborate rank determinations. Only two sections provided the material necessary to produce significant spectral curves; these are presented in Figure 2. Section 555-46-6 from early Eocene carbonaceous mudstones (sub-bottom depth, $470 \mathrm{~m}$ ) yielded a spectral curve characteristic of sporinites from the peat stage, with its sharp upswing at the lower end of the spectrum (Stach et al., 1982) and a peak at slightly less than $500 \mathrm{~nm}$. Section 60-6 from volcanoclastic sediments at $604 \mathrm{~m}$ sub-bottom depth, still early Eocene in age, showed a sporinite spectral fluorescence curve with a peak identical with that for Section 46-6 but lacking the upswing at the lower end. This second spectral curve also indicates a coalification stage below, though somewhat approaching that of the soft lignite. The respective $Q$-values (i.e., ratios of relative fluorescence intensities at 650 and $500 \mathrm{~nm}$, or red/green quotients, often used as an index of coalification) are also very low 
Table 2. Stratigraphic position of sections studied and vitrinite reflectance values determined.

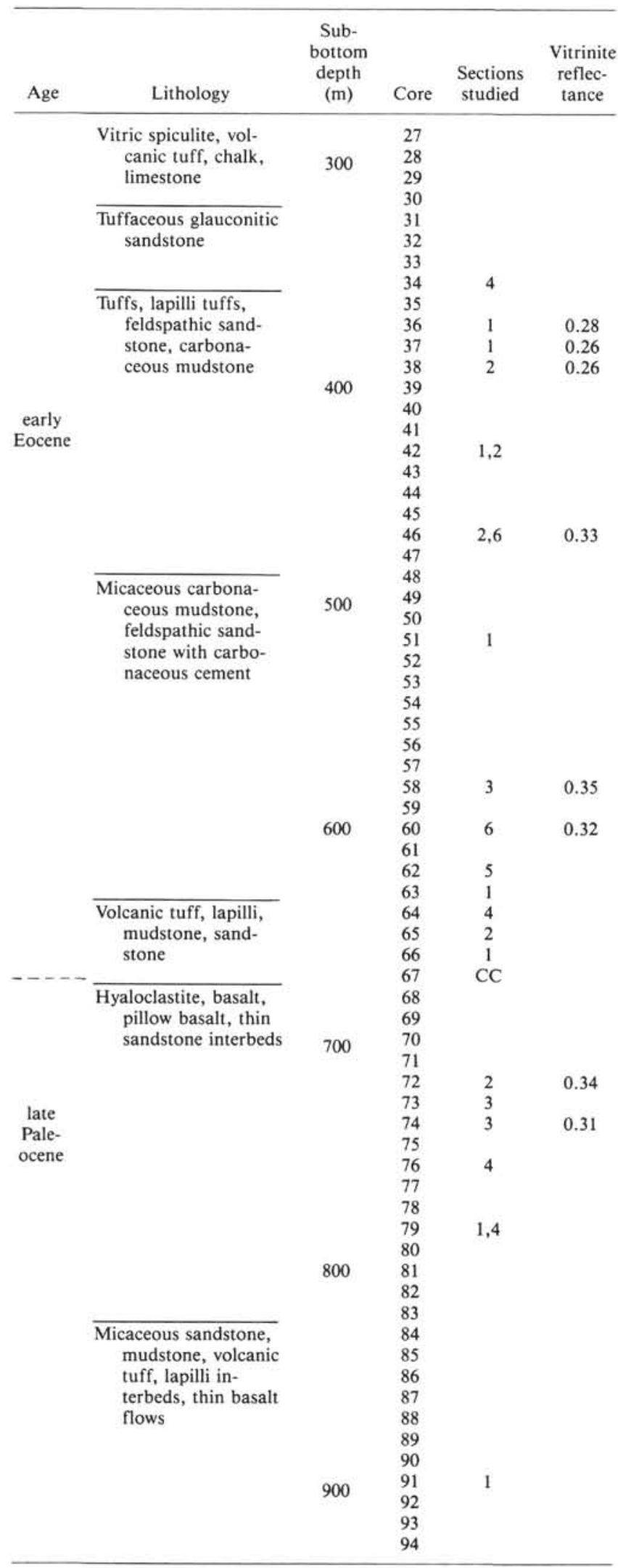

Table 3. Vitrinite reflectance values, Hole 555.

\begin{tabular}{lcrr}
\hline & \multirow{2}{*}{$\begin{array}{c}\text { Number } \\
\text { of }\end{array}$} & \multicolumn{2}{c}{$\begin{array}{c}\text { Vitrinite } \\
\text { reflectance }\end{array}$} \\
\cline { 3 - 4 } $\begin{array}{c}\text { Core-Section } \\
\text { (interval in cm) }\end{array}$ & $\begin{array}{c}\text { obser- } \\
\text { vations }\end{array}$ & $\begin{array}{c}\text { Range } \\
\left(\% R_{O}\right)\end{array}$ & $\begin{array}{c}\text { Mean } \\
\left(\% R_{O}\right)\end{array}$ \\
\hline $36-1,17-19$ & 19 & $0.23-0.34$ & 0.28 \\
$37-1,92-94$ & 13 & $0.23-0.30$ & 0.26 \\
$38-2,33-35$ & 13 & $0.20-0.33$ & 0.26 \\
$46-6,17-19$ & 12 & $0.29-0.40$ & 0.33 \\
$58-3,109-111$ & 13 & $0.24-0.45$ & 0.35 \\
$60-6,145-147$ & 12 & $0.24-0.46$ & 0.32 \\
$72-2,129-131$ & 1 & 0.34 & \\
$74-3,19-21$ & 1 & 0.31 & \\
\hline
\end{tabular}

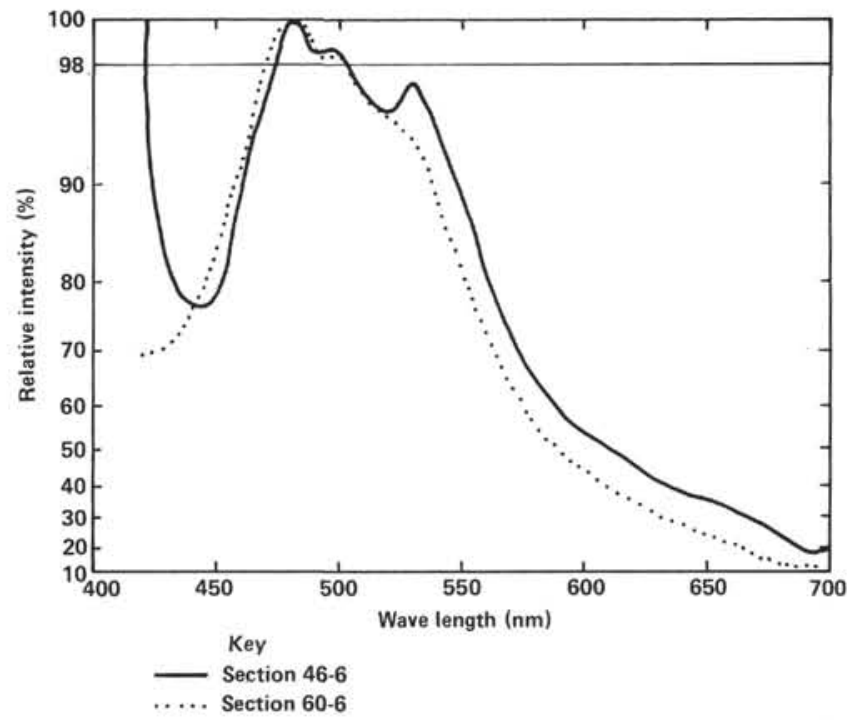

Figure 2. Fluorescence spectra of sporinites of Sections 555-46-6 and 60-6.

$(Q=0.36$ for Section $46-6$ and 0.23 for Section 60-6). The fluorescence spectra were made with a Leitz Ortholux II Pol BK microscope equipped with a high-pressure mercury lamp, a 50/1.00 W Leitz fluorescence objective, a dichromatic mirror (TK 400), a continuous interference filter (Veril B 60), and an EMI 9558-S20 cathode. UG1 and BG38 filters were used for uv-irradiation.

Alteration of fluorescence was not determined since suitable material was lacking.

\section{SUMMARY AND CONCLUSIONS}

The following conclusions can be drawn from the results of the petrographic investigation presented here:

1. Micropetrographic observations demonstrate the high degree of tissue degradation which prevents recognition of taxonomically significant structures. Only the phlobaphenitic cell fillings of tanniniferous tissues were preferentially preserved.

2 . The maceral content clearly shows the extreme predominance of terrestrial plant material. Macerals attributable to aquatic marine or fresh-water plants, especially algae, have not been observed beyond doubt, though the presence of forams and bivalves clearly implies deposition in a subaqueous environment. 
3. Most sclerotinite macerals (fungal sclerotia, teleutospores, and fungal plectenchyma) were derived from subaerial aerobic environments and apparently supplied by transport from a terrestrial source, probably through the same pathway as the huminitic macerals.

With deposition on the seafloor and incorporation in the sediment, the plant fragments became the site of bacterial sulfate reduction, while a generally oxygen-deficient environment was turned from postoxic to sulfidic (following the classification of Berner, 1981) in microenvironments provided by the plant tissue. Framboidal pyrite is commonly thought to be formed by the activity of sulfate-reducing bacterial colonies and to be indicative of sapropelic conditions (Fabricius, 1961). The fact that rather inert materials such as a fusinite, sclerotinite, and phlobaphenites host pyritic framboids almost as often as do the more reactive huminitic materials suggest that shielding was more important than chemical reactivity for the formation of strongly reducing microenvironments and that the general environment in surficial sediments was oxygen-poor but not oxygen-free. The high degree of degradation of plant material is thought to be the result of successive occurrences of aerobic and anaerobic decomposition.

4. From visual inspection at low magnification the amount of organic material present in the sediments may be greatly overestimated because of the high degree of pyritization. By volume and weight, some plant fragments consist of more pyrite than organic matter.

5. The low rank of maturity of organic matter, as shown particularly by the fluorescence spectra, shows Site 555 to be a particularly cold region. A coalification stage at the transition between peat and lignite cannot be maintained over the 50-to-60 million-year period that elapsed since sedimentation unless temperatures remain at levels which have no effect on organic maturation, i.e., below about $50^{\circ} \mathrm{C}$. As Gretener and Curtis (1982) point out only a short residence time at higher temperatures (above $100^{\circ} \mathrm{C}$ ) may have profound effects on the maturity level. It follows that heat flow from volcanic sources in the region during the time of sedimentation must have been negligible.

Vitrinite reflectance values from passive continental margins generally seem to be within the same range as those from Site 555 (Kendrick, Hood, and Castaño, 1979), but comparable sporinite fluorescence spectra have not been available to us as yet. The intrabasaltic coals of $\mathrm{Pa}$ leocene age from the Faeroe Islands, however, have considerably higher vitrinite reflectance values (mean: $0.42 \%$ $R_{o}$ ) attributable at least in part to the greater overburden $(\sim 2000 \mathrm{~m})$ of basalt there.

\section{ACKNOWLEDGMENTS}

We are particularly indebted to Mr. J. Klein-Reesink for his invaluable technical assistance, particularly with regard to fluorescence measurements as well as for many useful discussions. Thanks are due to Mr. B. Maul for the preparation of polished sections.

\section{REFERENCES}

Berner, R. A., 1981. A new geochemical classification of sedimentary environments. J. Sediment. Petrol., 51(2):359-365.

Fabricius, F., 1961. Die Strukturen des "Rogenpyrits" (Kössener Schichten, Rät) als Beitrag zum Problem der "vererzten Bakterien." Geol. Rdsch., 61:647-657.

Gretener, P. E., and Curtis, C. D., 1982. Role of temperature and time on organic metamorphism. Bull. Am Assoc. Petrol. Geol., 66(8): 1124-1149.

Kendrick, J. W., Hood, A., and Castaño, J. R., 1979. Petroleum generating potential of sediments from Leg 48, Deep Sea Drilling Project. In Montadert, L., Roberts, D. G., et al., Init. Repts. DSDP, 48: Washington (U.S. Govt. Printing Office), 951-954.

Stach, E., Mackowsky, M.-Th., Teichmüller, M., Taylor, G. H., Chandra, D., and Teichmüller, R., 1982. Stach's Textbook of Coal Petrology, (Third ed.): Berlin, Stuttgart (Gebr. Borntraeger).

Date of Acceptance: August 29, 1983 

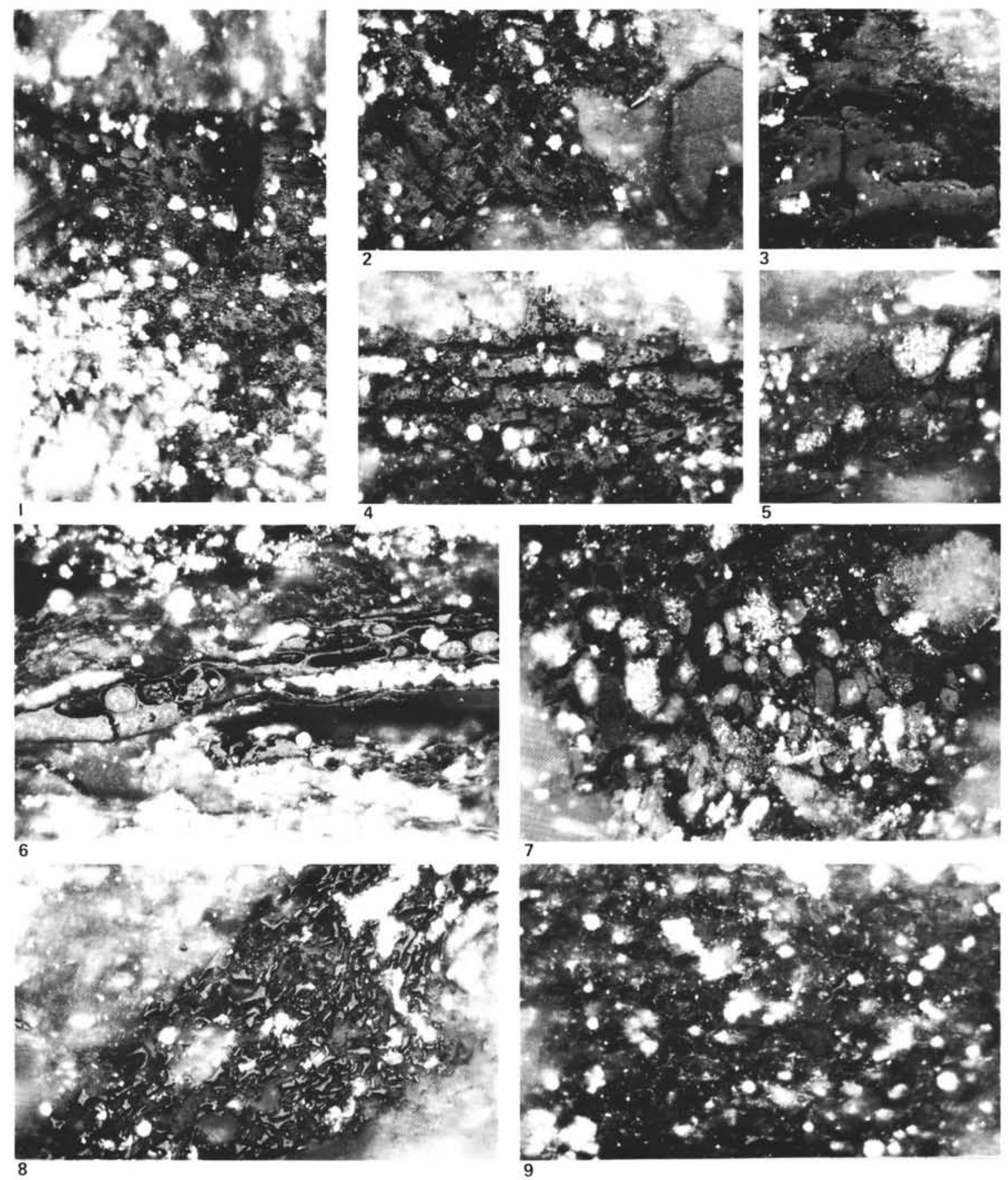

Plate 1. All magnifications $400 \times$, reflected light, oil. 1. Cross section of plant fragment showing transition from cluster of corpohuminites through attrinite to dense aggregates of pyritic framboids; probably represents a natural degradational sequence from top to bottom; Section 46-6. 2. Isolated particle of gelified humic detritus (densite); Section 46-6. 3. Isolated particle of levigelinite (eugelinite) with desiccation cracks; embedded in mineral matrix; Section 46-6. 4. Cluster of phlobaphenites showing original tissue connection; some cross sections of fungal hyphae but no cell walls; some pyrite present; Section 46-6. 5. Porigelinite and pyritized corpohuminites with surrounding cell walls partially intact; Section 46-6. 6. Textinite B (nonfluorescing) with partially pyritized phlobaphenitic cell fillings; probably represents a woody fragment with cross-sections of medullary rays; Section 38-2. 7. Cluster of various corpohuminites, in part pyritized, original tissue connection largely disaggregated; remnants of cell walls visible in upper left; Section 46-6. 8. Highly decomposed textinite, decomposition having taken place at least partly in situ; Section 38-2. 9. Fine-grained and disseminated attrinitic huminite embedded in pocket of fine-grained mineral matter; pyritic framboids evenly distributed; Section 46-6. 

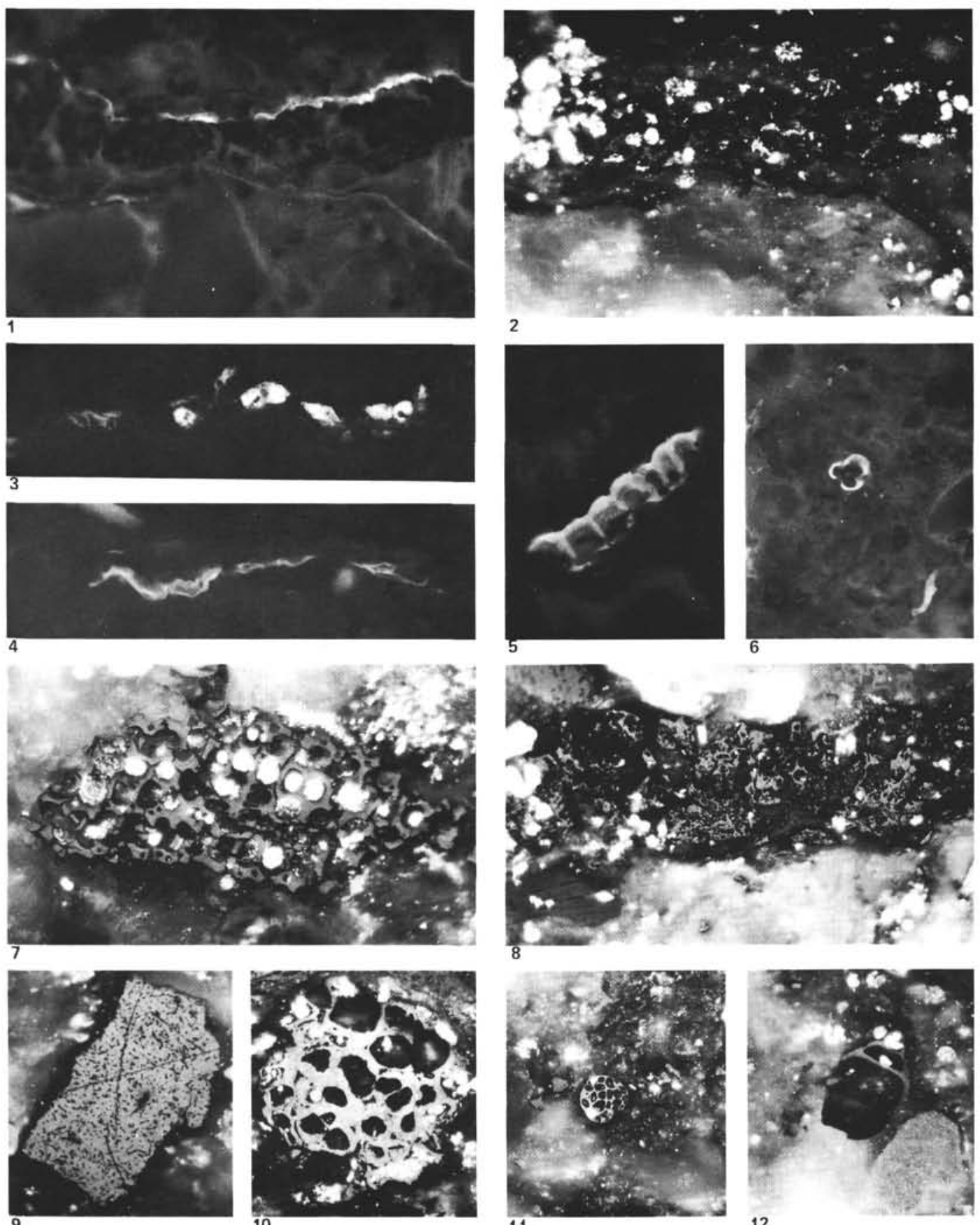

Plate 2. All magnifications $400 \times$. 1. Cross section through highly decomposed leaf bordered by thin cutinite partially detached; Section 46-6, fluorescence. 2. Same view as Figure 1 under normal reflected light, showing clusters of corpohuminites, but not cell wall material, and concentrations of pyritic framboids within the bounds of the leaf cross section. 3. Band of resinite within highly decomposed textinite; Section 38-2; fluorescence. 4. Alginite?, algal membrane? Section 38-2; fluorescence. 5. Fragment of thick-walled cutinite; Section 46-6; fluorescence. 6. Tricolpate pollen grain filled with framboidal pyrite, Section 46-6; fluorescence. 7. Fragment of pyrofusinite, partially pyritized; Section 38-2; normal reflected light. 8. Cross section through partially crushed fungal plectenchyma (sclerotinite); Section 38-2, normal reflected light. 9. Fragment of dense fungal plectenchyma (sclerotinite); Section 46-6; normal reflected light. 10. Sclerotites-type of fungal sclerotia (sclerotinite) with same pyrite-filled cavities; Section 46-6; normal reflected light. 11. Small fungal sclerotia embedded in fine-grained mineral matrix; Section 46-6; normal reflected light. 12. Teleutospore (sclerotinite), Section 46-6; normal reflected light. 